\title{
OTTONIAN GERMANY
}

THE CHRONICON

OF THIETMAR OF MERSEBURG

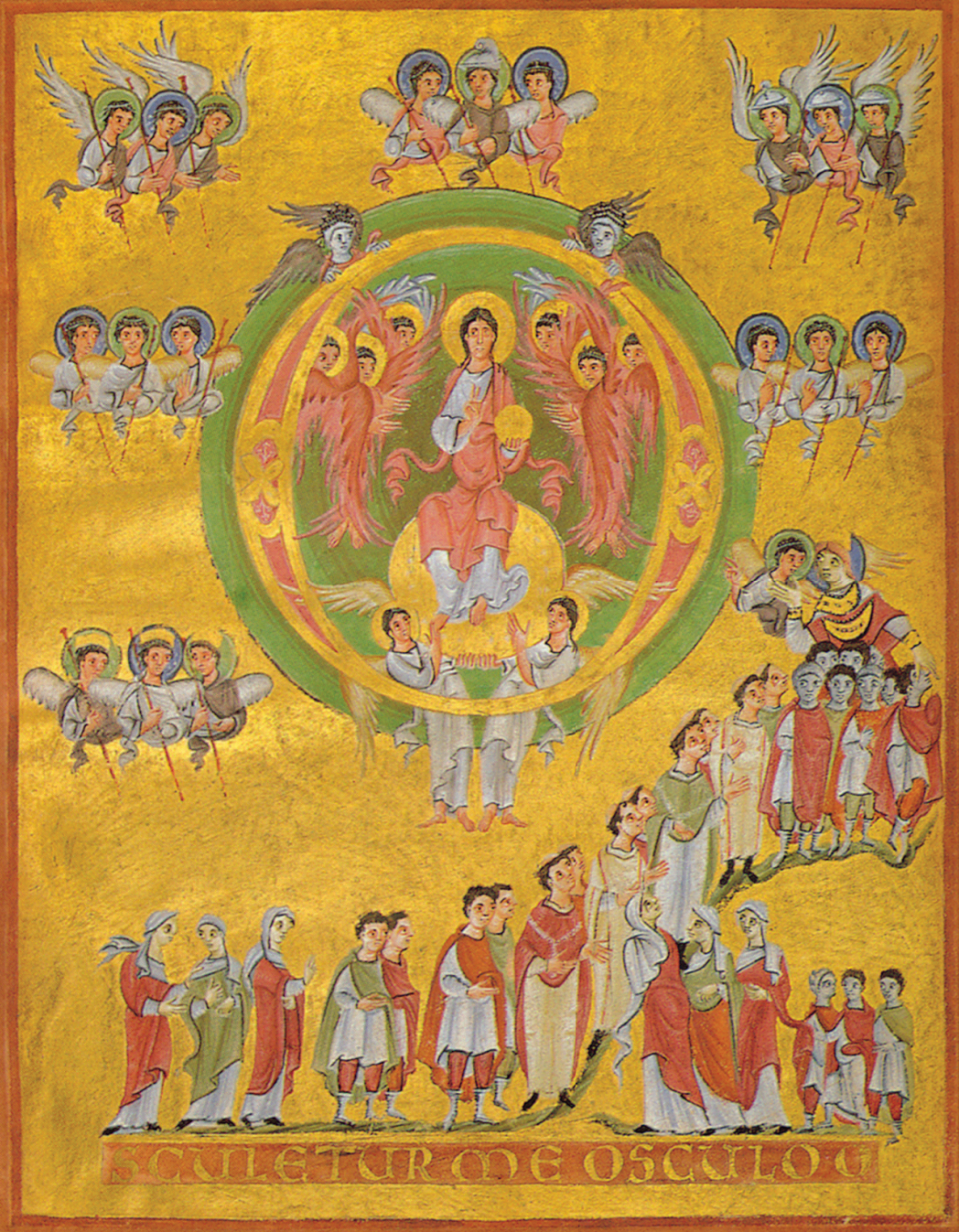

\section{Translated and annotated by David A. Warner}




\section{Manchester Medieval Sources Series}

series advisers Rosemary Horrox and Janet L. Nelson

This series aims to meet a growing need amongst students and teachers of medieval history for translations of key sources that are directly usable in students' own work. It provides texts central to medieval studies courses and focuses upon the diverse cultural and social as well as political conditions that affected the functioning of all levels of medieval society. The basic premise of the series is that translations must be accompanied by sufficient introductory and explanatory material, and each volume, therefore, includes a comprehensive guide to the sources' interpretation, including discussion of critical linguistic problems and an assessment of the most recent research on the topics being covered.

\section{already published in the series}

Simon Barton and Richard Fletcher The world of El Cid: Chronicles of the Spanish reconquest

J. A. Boyle Genghis Khan: history of the world conqueror

Trevor Dean The towns of Italy in the later Middle Ages

John Edwards The Jews in Western Europe 1400-1600

Paul Fouracre and Richard A. Gerberding Late Merovingian France

P. J. P. Goldberg Women in England c. 1275-1525

Janet Hamilton and Bernard Hamilton Christian dualist heresies in the Byzantine world c. $650-$ c. 1450

Rosemary Horrox The Black Death

Graham A. Loud and Thomas Wiedemann The history of the tyrants of Sicily by 'Hugo Falcandus' 1153-69

R. N. Swanson Catholic England: faith, religion and observance before the Reformation

Elizabeth van Houts The Normans in Europe

Jennifer Ward Women of the English nobility and gentry 1066-1500

\section{OTTONIAN GERMANY}


Medieval Sourcesonline

Complementing the printed editions of the Medieval Sources series, Manchester University Press has developed a web-based learning resource which is now available on a yearly subscription basis.

Medieval Sourcesonline brings quality history source material to the desktops of students and teachers and allows them open and unrestricted access throughout the entire college or university campus. Designed to be fully integrated with academic courses, this is a one-stop answer for many medieval history students, academics and researchers keeping thousands of pages of source material 'in print' over the Internet for research and teaching.

titles available now at Medieval Sourcesonline include

John Edwards The Jews in Western Europe 1400-1600

Paul Fouracre and Richard A. Gerberding Late Merovingian France: History and hagiography 640-720

Chris Given-Wilson Chronicles of the Revolution 1397-1400: The reign of Richard II

P. J. P. Goldberg Women in England c. 1275-1525

Janet Hamilton and Bernard Hamilton Christian dualist heresies in the Byzantine world c. $650-$ c. 1450

Rosemary Horrox The Black Death

Graham A. Loud and Thomas Wiedemann The history of the tyrants of Sicily by 'Hugo Falcandus' 1153-69

Janet L. Nelson The Annals of St-Bertin: Ninth-century histories, volume I

Timothy Reuter The Annals of Fulda: Ninth-century histories, volume II

R. N. Swanson Catholic England: faith, religion and observance before the Reformation

Jennifer Ward Women of the English nobility and gentry 1066-1500

visit the site at wrwr.medievalsources.co.uk for further information and subscription prices 


\section{OTTONIAN GERMANY}

\section{THE CHRONICON \\ OF THIETMAR OF MERSEBURG}

translated and annotated by David A. Warner

Manchester University Press

Manchester and New York

distributed exclusively in the USA by Palgrave 


\section{Copyright (C) David Warner 2001}

The right of David Warner to be identified as the editor of this work has been asserted by him in accordance with the Copyright, Designs and Patents Act 1988.

Published by Manchester University Press

Altrincham Street, Manchester Mi 7JA, UK

http://www.manchesteruniversitypress.co.uk

British Library Cataloguing-in-Publication Data

A catalogue record for this book is available from the British Library

Library of Congress Cataloging-in-Publication Data applied for

ISBN 0719049253 hardback

o 719049261 paperback

First published 2001

$\begin{array}{lllllll}07 & 06 & 05 & 04 & 03 & 02 & 01\end{array}$

$\begin{array}{llllllllll}10 & 9 & 8 & 7 & 6 & 5 & 4 & 3 & 2 & 1\end{array}$

The publisher has no responsibility for the persistence or accuracy of URLs for any external or third-party internet websites referred to in this book, and does not guarantee that any content on such websites is, or will remain, accurate or appropriate.

Typeset in Monotype Bell

by Koinonia Ltd, Manchester 